\section{Maddox to step down from editor's chair at Nature}

London. Sir John Maddox (below), editor of Nature for 22 of the past 29 years, will retire "on or around" his seventieth birthday in November.

Macmillan Magazines Ltd, the publisher of Nature, says that it has already held discussions with a number of potential successors. The company hopes that Maddox will continue to be involved in the development of the journal after his retirement.

Maddox was first appointed editor of Nature in 1966, having started his professional career in 1949 as a lecturer in theoretical physics at the University of Manchester. $\mathrm{He}$ then became science correspondent of the Manchester Guardian and, later, coordinator of the Nuffield Science Teaching Project.

During his first spell as editor, the circulation of the journal doubled, to 22,000 . He was director of the Nuffield Foundation from 1975 to 1980 , when he returned to Nature and has since helped to build the number of subscribers - in particular by substantially increasing its international circulation - to 56,000 . He was knighted in the New Year Honours list in January this year.

"When John Maddox goes, it is bound to seem like the end of an era, but everyone hopes that his ongoing involvement [with Nature] will make the transition a seamless one," Nicholas Byam Shaw, the chairman of Macmillan, said on Monday.

Maddox says he intends to stay "very active", and, while maintaining links to the journal, he is also looking forward to doing "something quite different". He is currently writing a book on what science has yet to discover and says that "it might even be fun to teach a physics course again".

Maddox says that his main regret on vacating the editor's chair is that because it has provided him with "an automatic way of keeping up to date" he will have to work harder. In addition to his academic and journalistic career, he is an elected member of the Gwenddyr and Crickadarn Community Council in Powys, South Wales.

\title{
State university system sees 'devastating' cuts
}

Washington. Researchers at the State University of New York (SUNY), the largest public university system in the United States, are bracing themselves for budget cuts of up to one-third which, they fear, could undermine the university's status as a major research institution.

The threat to the US\$340 million research programmes carried out each year at SUNY has received less publicity than other threats facing the system's 400,000 students - and their parents. But faculty members at the the university's major research campuses, at Buffalo and Stony Brook, expect that the anticipated cuts will hit research by raising the cost of taking on graduate students, preventing good staff from obtaining tenure and encouraging a flight of existing staff from the system.

George Pataki, the recently elected Republican governor of New York state, has put forward a budget that would drastically cut the state government's direct contribution to SUNY, reducing it from $\$ 970$ million to $\$ 680$ million next year. The governor is believed to have hit the university hard because he feels that, in contrast to other 'services' such as public schools or the sewage system, the university can raise revenues by increasing student tuition fees.

Once all revenue sources have been included, SUNY's income is about US\$3 billion a year. The proposed US $\$ 290$ million cut therefore represents a reduction of 10 per cent. Last week, Frederic Salerno, a telecommunications executive who chairs the SUNY board of trustees, said the cuts would "devastate" the university. "Another course of action must be found," he said.

Pataki is expected to agree a budget with the Democrat-controlled state assembly and the Republican senate by 1 April. The state has previously allowed this deadline to slip for weeks or even months. But Pataki says he will shut down the state government if he does not get a budget by the agreed date, and the final figure is expected to be close to the governor's proposal.

SUNY's strongest political support has traditionally come from the Republican senators who represent upstate New York, where many the system's 60-odd campuses are located. But party loyalty has obliged them to support Pataki's budget in public. It has been left to Democrats such as Steven Englebright, a Long Island assemblyman who is also a geologist with SUNY at Stony Brook, to attack it. "This would destroy the university," says Englebright, adding that the cuts will encourage the best existing faculty to leave, and make it impossible to recruit replacements.

SUNY's \$340 million research programme makes it one of the largest research universities in the United States, spending about the same as the University of Michigan, Stanford or Cornell (although the University of California system spends more than twice as much across all its campuses). Half of SUNY's $\$ 340$ million goes on biomedical research, and most of the rest on chemistry, physics, engineering and environmental sciences.

Staff say that, like public university systems in Massachusetts and other northeastern states, SUNY suffers a widespread $\downarrow$

\section{Congress promises a bleak future for research}

Washington. The current squeeze on research budgets is unlikely to be a shortlived affair, if a committee of the US House of Representatives has its way. Last week, the House Budget Committee voted to cut US\$100 billion from federal agency budgets over the next five years, in order to off-set promised tax cuts.

To demonstrate that such a reduction is feasible, the committee has published a 45 page list of what it calls "illustrative Republican spending cuts". Although these are only suggestions - the budgets of individual agencies are decided by committees in the House and Senate they show which programmes Republican leaders believe to be expendable.

Among the recommendations are a 5 per cent reduction in research funding for the National Institutes of Health, and scaling back and delaying the National
Aeronautics and Space Administration's proposed Earth Observing System (EOS). Some of the ideas, such as eliminating the Department of Energy and the National Biological Survey are not new. But committee members seem to have changed their minds about an earlier suggestion; rather than scrapping the US Geological Survey complete, the agency is now only targeted for "significant reforms".

Appropriations committees are, in principle, free to follow these guidelines if they choose - or to ignore them. But if the $\$ 100$ billion reduction is approved by Congress within the next few months, the committees will have to find the cuts somewhere. And the budget committee plans another five-year spending reduction - this time because of the federal deficit, and up to four times as large - in May.

Tony Reichhardt 